\title{
THE EFFICIENCY OF RESOURCE USAGE IN THE SOCIAL HEALTH INSURANCE SYSTEM
}

\author{
PhD Cumpănaşu Ecaterina, Health Insurance House of Hunedoara, \\ ecumpanasu@cjashd.ro \\ PhD Student Văidean Viorela-Ligia, ,Babeş-Bolyai” University Cluj-Napoca, \\ viorela.vaidean@econ.ubbcluj.ro
}

\begin{abstract}
The public health expenses seem to properly mirror the development level of a country. The purpose of this paper is to study the evolution of the public health expenses in the world and in our country. The efficiency of the public health care activity is further appreciated through a series of indicators.
\end{abstract}

Keywords: social health insurance, the national unique social health insurance fund, public health expenses

JEL Codes: G22, G28, H51, I11, I18

\section{Comparative study of the public health expenses}

In the world's developed countries, there is a high percentage of the public health expenses, in the total socio-cultural expenses, total public expenses and in the GDP, compared to the developing countries, as it resides from the following table:

Table no. 1

The weight of public health expenses in the total socio-cultural expenses, public expenses and GDP, in different countries of the world

\begin{tabular}{|l|l|l|l|l|}
\hline \multirow{2}{*}{} & \multirow{2}{*}{ Country } & \multicolumn{3}{|c|}{ The weight of public health expenses } \\
\cline { 3 - 5 } & & $\begin{array}{l}\text { In the total socio-cultural } \\
\text { expenses }\end{array}$ & In the total public expenses & In GDP \\
\hline 1 & The Czech Republic & 24.1 & 17.7 & 7.2 \\
\hline 2 & Argentina & 12.4 & 7.5 & 1.9 \\
\hline 3 & Austria & 20.1 & 14.2 & 7.1 \\
\hline 4 & France & 26.1 & 16.6 & 10.5 \\
\hline 5 & Great Britain & 24.9 & 10.8 & 5.8 \\
\hline 6 & U.S.A. & 30 & 18.3 & 7.6 \\
\hline 7 & Germany & 22.7 & 14.3 & 7 \\
\hline
\end{tabular}

Source: Calculated on the date from Statistiques financières internationalles, Annuaire, 2003, F.M.I. ${ }^{l}$

In the developed countries, the health expenses represent approximately $5-10 \%$ of GDP, as compared to the developing countries, whose values are of $1-2 \%$ of GDP. There is a noticeable difference between these country categories, furthermore considering the fact that the developed countries even have larger GDP dimension, as compared with the developing countries.

The public health expenses reveal even more the development level of a country, because the well developed countries also have private health care systems, a lot of these being really evolved. For example, in the USA, health insurance is mainly realized through the market, through private health insurances realized by American insurance societies. This system is extremely

\footnotetext{
${ }^{1}$ Tănăsescu, P. - Managementul financiar al activității sanitare, Ed. Tribuna Economică, Bucureşti, 2004
} 
developed from a medical point of view, but it's only accessible to the rich people, that are able to pay the high insurance premiums. Moreover, the American health care system is un-equitable, although the American government financially supports the poor Americans through two programs (Medicare and Medicaid).

In Romania, the financial resources for health care increased as years went by in absolute sums, but were kept at a modest level from the relative point of view, in the total of public expenses and in the total of GDP, according to the following table:

Table no. 2

The evolution of the public health care expenses in Romania 1990-2004

\begin{tabular}{|l|l|l|l|l|}
\hline Indicators & $\begin{array}{l}\text { Public health expenses } \\
\text { (million lei) }\end{array}$ & $\begin{array}{l}\% \text { of the total public } \\
\text { expenses }\end{array}$ & $\begin{array}{l}\% \text { of the total socio- } \\
\text { cultural expenses }\end{array}$ & \\
\hline 1990 & 2.52 & 7.6 & 17.2 & 2.9 \\
\hline 1992 & 7.26 & 7.8 & 19.7 & 3.3 \\
\hline 1994 & 152.88 & 9 & 19.4 & 3.1 \\
\hline 1996 & 319.05 & 8.7 & 18.2 & 2.9 \\
\hline 1998 & 383.89 & 8.6 & 18.3 & 3.2 \\
\hline 1999 & 369.23 & 8.5 & 15.9 & 4 \\
\hline 2000 & 380.26 & 8.6 & 15.9 & 3.8 \\
\hline 2001 & 395.48 & 8.3 & 16.2 & 4.2 \\
\hline 2002 & 403.71 & 8.5 & 16.3 & 3.8 \\
\hline 2003 & 412.39 & 8.9 & 16.7 & 3.8 \\
\hline 2004 & 409.65 & 8.7 & 16.1 & 3.7 \\
\hline
\end{tabular}

Source: Anuarul Statistic al României, Comisia Națională pentru Statistică, Bucureşti 2005, pag. 230-233

From the presented data, the absolute volume of these expenses for 1990-2007 clearly increased, but their weight in the total public expenses is relatively constant, between 7,6 and 9\%. The weight of the health care public expenses in the GDP was above 3\%, except for 1992, 1993 and 1994. After 1998, the new financing system was introduced, administrated by the National health insurance House and based on the contribution payments of employees and employers.

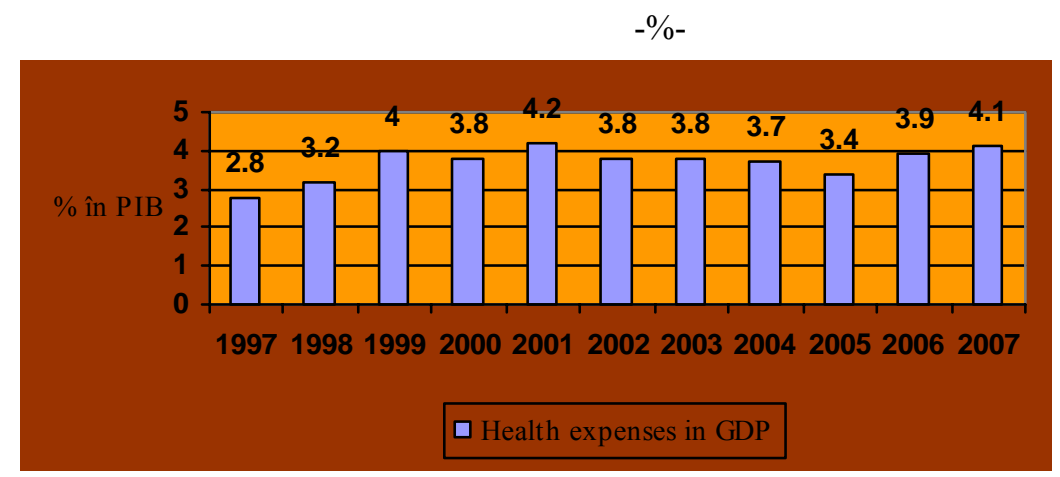

Fig. no. 1 - The evolution of the health expenses' weight in GDP

Source: http://www.cnas.ro

The peak of the weight of health expenses in the GDP between 1997-2007 was represented by the year 2006, with 4,9\%. The rhythm of the 2002-2004 period was a descending one, the year 2005 being a "crisis" one, with only 3,4\% of GDP. In 2007, health was given 4,12\% of GDP, with $3.041,5$ million lei above the 2006 budget allocation.

This oscillating evolution shows that the Romanian authorities did not have a coherent 
strategy for the health domain.

As compared to other countries belonging to Central or Eastern Europe, like Hungary, Croatia, The Czech Republic, that usually allocate 6-8\% of GDP, Romania is at the back of the health indicators' top.

\section{Study of the efficiency of the public health care activity in Romania}

The health care activity has a major influence upon the development of the national economy and GDP increase. It assures the basic need of the man to be healthy and of the society to have a healthy population. At a macro economical level, it contributes to the work force reproduction and general welfare specifically. effects.

Considering the importance of these expenses, it's compulsory to study their usage and their

The health care activity is materialized in various effect categories, like: medical effects, social effects and economical effects. These effects, considered on the whole, are tightly related to the efficiency of spending the allocated financial resources, especially public resources.

The medical effects aim the definite results of the medical actions (analysis, treatments, etc) and refer to cures or improvements, i.e. the renewal and maintenance of individual's health, benefiting from medical assistance.

The social effects reflect the results of health care actions for the whole society and they affect the health status of the whole population, being reflected through a series of statistical indicators like: birth rates, infantile mortality, etc.

The economical effects represent the economical benefits probable to realize.

The systematic study of the population's health, based on a scientific methodology, helps not only to the knowledge and interpretation of its level modifications, but, to a certain extent, it allows even the appreciation of the efficiency and quality of the medical institutions' activity.

Based on some studies of the National Statistic Committee, with data extracted in the above table, we may conclude the following appreciations regarding the population's expenses on medicines and health care as a percentage of the average income of a family:

Table no. 3

The weight of population's expenses for medicines and health care in the average income of a family

\begin{tabular}{|l|c|c|c|}
\hline \multirow{2}{*}{ Years } & \multicolumn{3}{|c|}{ Family categories } \\
\cline { 2 - 4 } & 1.Employees' families & 2.Peasants' families & 3.Pensioneers' families \\
\hline 1990 & 10 & 19 & 35.5 \\
\hline 1992 & 10.3 & 18.2 & 29.4 \\
\hline 1994 & 11.6 & 18.6 & 28 \\
\hline 1996 & 12.5 & 18.5 & 28.7 \\
\hline 1998 & 13.1 & 19.8 & 29.8 \\
\hline 1999 & 13.2 & 20 & 30 \\
\hline 2000 & 13.3 & 20.1 & 29.5 \\
\hline 2001 & 13.5 & 20.2 & 30.4 \\
\hline 2002 & 13.5 & 20 & 30.6 \\
\hline 2003 & 13.8 & 20.2 & \\
\hline
\end{tabular}

Source: Tănăsescu, P. - Managementul financiar al activităţii sanitare, Ed. Tribuna Economică, Bucureşti, 2004; Documentarea autorului la Direcția de statistică a Ministerului Sănătății, Bucureşti, 2002-2003

The analyzed percentages manifest a weak increasing tendency (relatively) not because of reaching an equilibrium level, but because of a money barrier (decreased money purchasing power) 
or a territorial lack of medical cabinets (rural zones of the country or under-developed urban zones); on the other hand, private investments mainly focused the medical domains with a low investment effort. This situation is owed to an obvious lack of private Romanian capital, and even to a weak implication of the banking sector in greater financing this deficitary but extremely useful domain.

Correlating with the usage structure of the National Unique Social Health Insurance Fund (NUSHIF) as it comes out of the following graph, some meaningful aspects may be concluded.

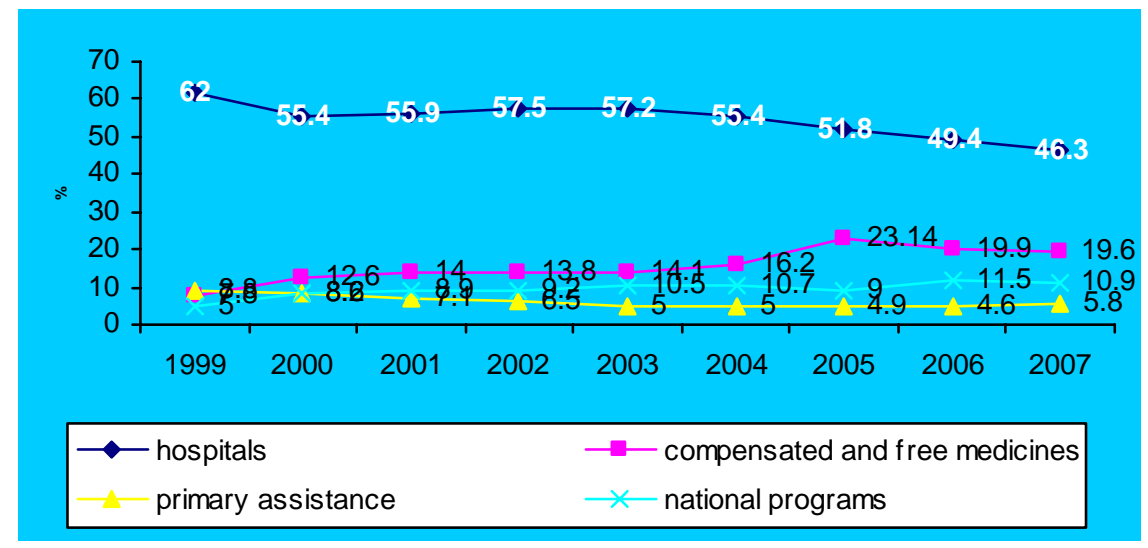

Fig. no. 2 - The evolution of the main expenses' weight in the NUSHIF between 1999-2007 - \% Source: http://www.cnas.ro

Noticing the evolution of the usage structure of the NUSHIF between 1999-2007, it's more than obvious that the expenses in the hospitals' sector have a clear descending tendency, from $62 \%$ of NUSHIF in 1999, to $46,3 \%$ in 2007 , a predictable level, although these expenses' category has a large weight in the resources' total amount. The main problem remains the efficient usage of these sums, as up to $70-80 \%$ from the resources allotted to hospitals are represented by personnel's salary expenses, the sums remaining for development and supplies of medicines, medical consumables and food for the patients being insufficient.

The graph also reveals the constant increase of the expenses for compensated and free medicines: from $8,8 \%$ in 1999 to $23,14 \%$ in 2005 -the peak, respectively $19,6 \%$ estimated level in 2007. The resources allocated for the national health programs evolved from $5 \%$ in 1999 to $10,9 \%$ in 2007 , i.e. more than double.

\section{Conclusions}

We have to mention that the social health insurance systems (Bismark model) face difficulties in certain periods (e.g. periods with increased unemployment, when the number of contributors is low, etc), when the intervention from the state budget is needed: the medical assistance for categories un-included on the labor market (e.g. the retired people) is traditionally covered from the state budget, which is not the case of our social health insurance system. So, we think that the contributions of the persons absolved from the payment of health insurance through special laws - pensioners, war veterans, revolutionists etc.-should be paid from the state budget, in order not to greatly affect the national unique social health insurance fund.

Moreover, when it comes to communication and action on behalf of the system's partners: The National health insurance House, The Health Ministry, political decedents, the Romanian Doctors' Association, we may notice barriers in the information flows, on the background of a weak educational system that transformed exceptions into rules. We may accuse the political ideologies and the authoritarian leadership style, the conceptual confusions or the contradictions between laws. We get to the situation that the National Health Insurance House is no longer able to fulfill its role, as long as the partners of the system don't respect their roles. The National Health Insurance House 
does not have autonomy as to governmental institutions (The Health Ministry coordination/control; The Public Finance Ministry - un-mixture in the fund's usage), and the exterior pressures cannot be neglected (the medical services providers want to "extend" the services defined in the basic package). It's more than obvious that, considering these conditions, we may not talk about well-defined rules, roles and responsibilities, specific to a system that theoretically wants to fulfill efficiency criteria (cost-efficacy, equity, quality) of a health care system ${ }^{2}$.

With all these, the existence necessity of medical services public system in Romania cannot be questioned, at least for the moment. And each active person's contribution - directly and through his/her employer - to the forming of the social health insurance fund is compulsory. The insured persons and the employers monthly pay a contribution to the social health insurances, as a $6,5 \%$ quota and $6 \%$ quota respectively, from their monthly income. Officially, the insured persons do not have to pay any other supplementary expenses for the medical services, except for the copayments for ambulatory prescribed medicines. The sums collected by the insurance houses are used according to the money-follow-the-patient principle, for paying the medical services of the contracted providers. The medical services the insured persons are entitle to are preventive medical assistance and health promoting services; ambulatory medical services; hospital medical services; dental services, emergency medical services; complementary re-habilitation services, pre-, intraand postnatal medical assistance; home medical assistance, medicines, sanitary materials and prostheses.

Although the social health insurances represent the main system of caring for population's health, for many of us, the package offered through this system covers only a small amount of the actual necessities for general medical controls, special controls and analysis. For being healthy, for preventing the apparition of diseases or for treating the existing ones, such medical investigations must be carried out periodically. This is why we must assure ourselves that we may whenever get to a high quality medical service provider.

Still, the Romanian private health insurance system is almost inexistent. So far, only a couple of insurance companies dared to offer health insurance policies that would guarantee a human treatment in hospitals. Presently, the number of privately health insured persons is relatively low, of only a couple of thousands nationally. There is another larger category of people that have a health subscription. The un-explored potential of this market remains huge.

\section{References:}

1. Alexandru, Gh. - 'Evaluarea eficienței activităților sanitare', Editura Lumina Lex, Bucureşti, 2002

2. Armean, P. - 'Management sanitar. Noțiuni fundamentale de sănătate publică', Editura Coresi, Bucureşti, 2006

3. Celea, C. - 'Organizarea sistemului sanitar național', Editura Coresi, Bucureşti, 2005

4. Preda, M. - 'Politica socială românească între sărăcie şi globalizare', Editura Polirom, Bucureşti, 2002

5. Tănăsescu, P. - 'Managementul financiar al activității sanitare', Editura Tribuna Economică, Bucureşti, 2004

6. Țurlea, E. - 'Managementul financiar al sistemului de sănătate', Suport de curs Universitatea Bucureşti, Facultatea de Sociologie şi Asistență Socială, Master 'Managementul Sistemului de sănătate', 2005

7. www.cnas.ro

\footnotetext{
${ }^{2}$ Dr. Celea, C. -,„Organizarea sistemului sanitar naţional”, Bucureşti 2005
} 